\title{
Land Banks' Impact on Agrarian Reform and Equitable Land Redistribution
}

\section{Iswantoro $^{1}$ Resti Dian Luthviati ${ }^{\mathbf{2}}$}

${ }^{1}$ Faculty of Shariah and Law, Universitas Islam Negeri Sunan Kalijaga, Yogyakarta, Indonesia. ${ }^{2}$ Program Study of Demography and Civil Registration, Universitas Sebelas Maret, Indonesia.

\begin{tabular}{l}
\hline Info Artikel \\
Keywords: \\
Standarization, Halal Tourism, \\
West Nusa Tenggara \\
\\
Kata kunci: \\
Standarisasi; Pariwisata Halal; \\
Nusa Tenggara Barat. \\
Corresponding Author: \\
Resti Dian Luthviati, E-mail: \\
restiadianluthviati@staff.uns.ac.id \\
E-ISSN: 1412-6605 \\
2301-6426 \\
Pals
\end{tabular}

Abstract

Agrarian Reform and Land Redistribution have been pursued by the government in various ways. Still, the key question is whether establishing a Land Bank will result in a fair redistribution of land. The purpose of this study is to examine the impact of land banks on agrarian reform and equitable land redistribution following the passage of the Job Creation Act. The findings revealed that the land bank only has a few abandoned lands that are not held by the state, which will be used by the form based on public interest and subsequently handed to the community. The existence of a land bank is a government endeavor to offer land for the public good and for persons who require it.

Abstrak
Reforma Agraria dan Redistribusi Tanah telah
diupayakan oleh pemerintah dengan berbagai cara.
Namun, pertanyaan kuncinya adalah apakah pendirian
Bank Tanah akan menghasilkan redistribusi tanah yang
adil. Tujuan dari penelitian ini adalah untuk mengkaji
dampak bank tanah terhadap reforma agraria dan
pemerataan redistribusi tanah setelah disahkannya UU
Cipta Kerja. Temuan mengungkapkan bahwa bank
tanah hanya memiliki tujuan untuk mengurus tanah
terlantar yang tidak dimiliki oleh negara, yang akan
digunakan bentuk berdasarkan kepentingan umum dan
selanjutnya diserahkan kepada masyarakat. Keberadaan
bank tanah merupakan upaya pemerintah untuk
menawarkan tanah untuk kepentingan umum dan
orang-orang yang membutuhkannya.




\section{Introduction}

On November 2, 2020, Law Number 11 of 2020 concerning Job Creation was ratified. The legislation has both advantages and disadvantages, particularly in relation to the Land Banks rule. The Land Bank, according to the chairman of the National Legislation Agency, is a step forward in agrarian reform. The government plans to speed up agricultural reform and the Land Bank's land redistribution. ${ }^{1}$ The presence of this Land Bank is an example of the government's efforts to offer land for the public good and the needs of those who require it. The existence of a Land Bank will considerably assist the government in purchasing land, which will eventually be created for public facilities such as roads, infrastructure, hospitals, government offices, and so on, especially in the public interest area. ${ }^{2}$

This institution is properly implemented, the number of cases in court challenging the value of land compensation for the public good (consignment) will decrease. MPR Decree Number IX/MPR/2001 concerning Agrarian Reform and Natural Resource Management (Tap MPR No. IX/2001) has yet to be issued following the publication of Law No. 5 of 1960 concerning Basic Regulations on Agrarian Principles (hereinafter referred to as UUPA). The government has made various efforts to boost national development by enacting legislation and regulations that particularly operationalize the agricultural reform program in the context of achieving a just and affluent society. ${ }^{3}$

In Article 33, paragraph (3) of the 1945 Constitution of the Republic of Indonesia, it is stated that the earth, water, and the wealth or assets contained therein are controlled by the state and used for the greatest prosperity of the people. Article 1 paragraph (2) of Law Number 5 of 1960 concerning Basic Regulations on Agrarian Principles, after this abbreviated as UUPA, which reads: "All earth, water, and space, including the natural resources contained therein within the territory of the Republic of Indonesia as a gift from God. The Supreme Being is the earth. The Indonesian people's water and space are a national wealth" . ${ }^{4}$ Article 33 paragraph (3) of the 1945 Constitution states that the Earth, water, and natural resources contained therein, whose control is assigned to the State of the Republic of Indonesia, must be used for the prosperity of the people. Where the word power in Article 33 paragraph (3) of the 1945 Constitution above,

\footnotetext{
${ }^{1}$ Moh Iqra, Syabani Korompot, and Al-fatih David, 'The Principle of Equality Before the Law in Indonesian Corruption Case : Is It Relevant?', Journal of Human Rights, Culture and Legal System, 1.3 (2021), 135-46.

2 Tewodros Tadesse and others, 'Willingness to Accept Compensation for Afromontane Forest Ecosystems Conservation', Land Use Policy, 105.September 2020 (2021), 105382 <https://doi.org/10.1016/j.landusepol.2021.105382>.

${ }^{3}$ Devi Triasari, 'Right to Sanitation : Case Study of Indonesia', Journal of Human Rights, Culture and Legal System, 1.3 (2021), 147-63 <https://doi.org/10.53955/jhcls.v1i3.20>.

${ }^{4}$ Iqra, Korompot, and David.
} 
according to the general explanation of the UUPA, does not mean that it is owned, but it gives authority to the state, as the organization of power of the Indonesian Nation, at the highest level. ${ }^{5}$

The Indonesian nation is also one of the countries with an agricultural background where land is a significant thing and has a high value in people's lives, it can be said that land is a source of energy for the Indonesian people who have various natural resources as space for development. The land is the principal capital in implementing development to realize the creation of prosperity in society. ${ }^{6}$ Through a government agency or an independent agency appointed by the government, a state is authorized to acquire abandoned land, manage and temporarily regulate it, and distribute it for the public interest. This is a land policy called the Land Bank. ${ }^{7}$

The Land Bank is an institution that carries out a land management function by definition. The process of this arrangement is extensive in scope, such as planning, acquisition, management, utilization, and distribution of land as regulated in the Job Creation Law. The concept of the Land Bank has been present in the westernmost part of Indonesia, namely in Aceh, which is known as the Baitul Mal institution, and on the island of Sulawesi, namely Makassar City. Management of abandoned land by Baitul Mal uses Land Bank and ihya 'almawat. Baitul Mal acts as the manager of religious assets according to Islamic Shari'a to determine the status of abandoned land and allocate it to the community so that it can be empowered/activated/appropriately managed to develop the community's welfare. On the one hand, the use of abandoned land to the community can be granted with lease rights or other rights to ground according to applicable regulations. ${ }^{8}$

It can be said that establishing an institution that handles land acquisition is very important to avoid inequality of land/availability with the Government's efforts to carry out development. Based on Article 6 of Law Number 5 of 1960 concerning Agrarian Principles, every land has a social function, which means that the beneficial use of the land can not only be owned by the owner of land

\footnotetext{
${ }^{5}$ Ratna Sofiana, Satria Utama, and Abdur Rohim C, 'The Problems of Halal Certification Regarding Consumer Protection in Malaysia and Indonesia', Journal of Human Rights, Culture and Legal System, 1.3 (2021), 180-93 <https://doi.org/https://doi.org/10.53955/jhcls.v1i3.16>.

${ }^{6}$ Utkarsh K Mishra and Abhishek Negi, 'Should Trade Remedies Be Eliminated from WTO : A Response to Tania Voon', Journal of Human Rights, Culture and Legal System, 1.3 (2021), 194-200.

${ }^{7}$ Resti Dian and Suviwat Jenvitchuwong, 'Implementation of Halal Product Assurance in the Pharmaceutical Sector in Indonesia', Journal of Human Rights, Culture and Legal System, 1.3 (2021), 164-79 <https://doi.org/https://doi.org/10.53955/jhcls.v1i3.19>.

8 Arif Purnama Oktora and Hilaire Tegnan, 'Strategy for Implementing Operations to Handle the Crime of Narcotics', Journal of Human Rights, Culture and Legal System, 1.3 (2021), 201-13.
} 
rights and for the wider community (public interest)..$^{9}$ Procurement of land for development in the public interest is an activity of providing ground by providing appropriate compensation for those entitled to it. The government can use the current instrument to provide land for development through land consolidation and land readjustment mechanisms. Land consolidation means managing land use in rural areas related to agricultural or forestry sites, which have a divided ownership structure to increase agricultural productivity. ${ }^{10}$

In contrast, Land Readhysment means managing land use in urban areas, especially in areas with high land-use intensity through reorganization of builtup land and adjustments. Land parcels improve the quality of services and the lives of urban communities. With the increasing difficulty of obtaining land for the development of various interests and the expanding value of land, one of the things that have become government policy is implementing and procuring the land bank concept. ${ }^{11}$

The government, through Law Number 11 of 2020 concerning Job Creation, plans to establish a Land Bank institution that aims to accommodate several abandoned and unoccupied lands to be utilized by the state based on public interest, according to the Minister of Agrarian Affairs and Spatial Planning/National Land Agency or ATR/BPN Sofyan Ahmad Djalil, Landbank is essentially an intermediary system, namely the state takes land, land that is not occupied, such as HGU, abandoned HGB. Land that is not owned by the state will be taken back by the state to be distributed to the community. A land bank is needed to ensure public interest, social interest, development interest, social, economic equity, land consolidation economy, and agrarian reform. The government seems to see that this land bank can be a land management company, seeing that the government takes no strategic policy to provide land, which is a big obstacle in the land sector. ${ }^{12}$

However, the mechanism for the procurement of a land bank in which the right is used as a new institution certainly requires further reviews and several stages in its procurement and implementation of activities. However, in 2019 the Land Bill was canceled. The background of the cancellation of the ratification of

${ }^{9}$ Ana Rosa Gonzalez-Martinez and others, 'Aligning Agricultural Production and Environmental Regulation: An Integrated Assessment of the Netherlands', Land Use Policy, 105.773499 (2021), 105388 <https://doi.org/10.1016/j.landusepol.2021.105388>.

${ }^{10}$ Yuei An Liou, Kim Anh Nguyen, and Le Thu Ho, 'Altering Urban Greenspace Patterns and Heat Stress Risk in Hanoi City during Master Plan 2030 Implementation', Land Use Policy, 105 (2021), $105405<$ https://doi.org/10.1016/j.landusepol.2021.105405>.

${ }^{11}$ B. Kabigi, Walter T. de Vries, and H. Kelvin, 'A Neo-Institutional Analysis of Alternative Land Registration Systems in Tanzania: The Cases of Babati and Iringa Districts', Land Use Policy, 105.April (2021), $105435<$ https://doi.org/10.1016/j.landusepol.2021.105435>.

12 Tonya Smith and Janette Bulkan, 'A "New Relationship"? Reflections on British Columbia's 2003 Forest Revitalization Plan from the Perspective of the Lilwat First Nation', Land Use Policy, 105.April (2021), 105345 <https:/ / doi.org/10.1016/j.landusepol.2021.105345>. 
the Land Bill at the end of 2019 was due to pressure from the community to review all articles, where the Land Bill was considered not to represent the soul of the UUPA and was contrary to reforms in the land sector and considered only administrative registration land. It needs to be considered again because there are still many problems regarding land in this country of Indonesia. One of the complex problems that often occur in the Indonesian land sector is the provision of land for development needs, especially in urban areas..$^{13}$

This scarcity causes land prices in urban areas to rise, and the estimated land price based on the Tax Object Sales Value (NJOP) does not apply. The determination of land prices is based on the market price mechanism arising from imperfect competition. The acquisition of land prices for development requires very high costs for compensation payments. The increasing intensity of development needs and the increasingly limited availability of land simultaneously make it increasingly difficult to optimize the utilization of land use, especially for the implementation of development for the public interest, which results in conflicts of interest between parties over the same piece of land.14

The land is an essential medium for a development process for the main public interest which requires a substantial amount of land. The problem that most often occurs is when the government wants to start development. The desired land is not available or not yet public. The practical consequence is that the government has difficulty carrying out the land acquisition process, especially related to the execution of land acquisition and its financing, which is very expensive. This condition resulted in a protracted procurement process. The complicated land acquisition then made the rights of other parties, namely the government or the private sector, who needed more and could utilize the plot of land immediately become unfulfilled so that the potential for welfare that would be obtained could not be obtained realized. ${ }^{15}$

Currently, the government must focus on the infrastructure development that the community most needs, particularly in terms of ensuring the availability of development land, especially as the community's need for land grows in tandem with its population. ${ }^{16}$ It is critical to establish a land acquisition organization in

${ }^{13}$ Brian Danley, Therese Bjärstig, and Camilla Sandström, 'At the Limit of Volunteerism? Swedish Family Forest Owners and Two Policy Strategies to Increase Forest Biodiversity', Land Use Policy, 105.March (2021) <https:// doi.org/10.1016/j.landusepol.2021.105403>.

${ }^{14}$ Kon Kim, Blaž Križnik, and Krystallia Kamvasinou, 'Between the State and Citizens: Changing Governance of Intermediary Organisations for Inclusive and Sustainable Urban Regeneration in Seoul', Land Use Policy, 105.March (2021) <https:// doi.org/10.1016/j.landusepol.2021.105433>.

${ }^{15}$ Alison Caffyn, 'Broiler Battles: Contested Intensive Poultry Unit Developments in a Policy $\begin{array}{lllll}\text { Void', } \quad \text { Land } & 105415\end{array}$ $<$ https://doi.org/10.1016/j.landusepol.2021.105415>.

${ }^{16}$ Svetislav G. Popović, Milica Dobričić, and Sanja Vlahović Savić, 'Challenges of Sustainable Spatial Development in the Light of New International Perspectives - The Case of Montenegro', Land Use Policy, 105.April (2021) <https:/ / doi.org/10.1016/j.landusepol.2021.105438>. 
order to eliminate disparities in land availability that impede the government's development initiatives. This is because land acquisition for the public good strives to offer land for the implementation of a product that will promote the nation's, state's, and society's welfare and prosperity while also safeguarding the legal interests of the landowners who are entitled to the land.

\section{Results and Discussion}

\section{Definition and Legal Basis of Land Bank}

According to the book "the best practice land bank," a land bank is an institution formed to promote the revitalization or revitalization of the property's environment, particularly for realignment of ownership and use, housing, and settlements in urban areas, as well as several developments that result in an industrial/commercial application of the land bank's authority. Land banks in the public sector as a mechanism for addressing urban renewal difficulties, ensuring the long-term viability of open space, and stabilizing land values. Additionally, the land bank can be defined as the practice of distributing land beginning with the purchase or acquisition of property to be developed later to satisfy future demands. Additionally, the land bank is a notion for gaining access to land for public service objectives such as housing, industry, and agriculture through property speculation, market directing, and land management. ${ }^{17}$

The fundamental distinction between the Land Bank and the National Land Agency is that the Land Bank, established under copyright law, performs a derivative role of the National Land Agency. In Indonesia, the land bank supervises land planning, acquisition, distribution, and management. Meanwhile, the National Land Agency performs a similar duty to that of the land bank. The probable distinction is that the land bank can be understood as both a repository of data and an executor of land interests, whilst the National Land Agency becomes the primary regulator, serving as the focal point for different land-related decisions, coordination, and execution orders. Another distinction is in the scope of the National Land Agency's responsibilities, which include the authority to resolve land disputes that arise in the community. The National Land Agency serves as an alternate venue for the community to resolve land-related disputes, in addition to the courts. ${ }^{18}$

${ }^{17}$ C. Hérivaux and others, 'Combining Narrative Scenarios, Local Knowledge and Land-Use Change Modelling for Integrating Soil Erosion in a Global Perspective', Land Use Policy, 105.March 2020 (2021) <https:/ / doi.org/10.1016/j.landusepol.2021.105406>.

18 Maryam Pourzakarya and Somayeh Fadaei Nezhad Bahramjerdi, 'Community-Led Regeneration Practice in Ghalam Gudeh District, Bandar Anzali, Iran: A Participatory Action Research (PAR) Project', Land Use Policy, 105.April (2021), 105416 <https://doi.org/10.1016/j.landusepol.2021.105416>. 
A land bank is institutionally subordinate to the president and is governed by a supervisory board. The land bank's role as land management is focused on four objectives. To begin, land management must prioritize the public interest, development, and social and agrarian transformation. As a special agency, the land bank is responsible for managing land with management rights (HPL), which includes planning, acquiring, procuring, managing, utilizing, and distributing land. Thus, the land bank's existence serves the public interest. ${ }^{19}$

Additionally, a supervisory board and an executive board exist. The deployment of land bank technology in Indonesia is critical. It can support a variety of land policies through the Land Bank. Land bank policies relating to land provision are prevalent, with the objective of providing government land stocks for diverse future development needs, conserving the government budget (APBN/APBD), and reducing land acquisition conflict. The Employment Creation Act prioritizes the Land Bank's establishment and general provisions. ${ }^{20}$ The Land Bank is also included in an Omnibus Law, which consolidates several legislation. This demonstrates the critical nature of the Land Bank's presence. In terms of its function, Land Banking has several tasks, according to Siregar (2004) in Annaningsih (2007), as follows: ${ }^{21}$

1. Land keeper, as a land collector, namely inventory and development of land databases, administration, and provision of land information systems.

2. Land warrant, as land security, ensures the provision of land for development, guarantees land value and land market efficiency that is just, and secures optimal land use.

3. As a land controller, land tenure and land price determination are related to the similarity of land and building tax values.

4. As a land appraiser, a land valuer conducts an objective land appraisal to create a value system in determining the value of land applicable for various purposes.

${ }^{19}$ Robert Sroka, 'Does the Arena Matter? Comparing Redevelopment Outcomes in Central Dallas Tax Increment Financing Districts', Land Use Policy, 105.March (2021), 105431 <https://doi.org/10.1016/j.landusepol.2021.105431>.

${ }^{20}$ Dwi Amalia Sari and others, 'Evaluating Policy Coherence: A Case Study of Peatland Forests on the Kampar Peninsula Landscape, Indonesia', Land Use Policy, 105.31 (2021), 105396 <https://doi.org/10.1016/j.landusepol.2021.105396>.

${ }^{21}$ Şerife Tülin Akkaya Aslan, 'Evaluation of Land Consolidation Projects with Parcel Shape and Dispersion', Land Use Policy, 105.March (2021) <https://doi.org/10.1016/j.landusepol.2021.105401>. 
5. As a land distributor, land distributor ensures a fair and fair distribution of land based on the unity of land values, securing the planning, provision, and distribution of land.

6. As a land manager, land management is carrying out land management, which is part and overall asset management, conducting analysis, determining strategies, and managing implementation related to land.

The government makes a legal reference to Article 33 of the 1945 Constitution. As a result, the state must govern land authority, management, and use. It was then reinforced in Article 2 of 1960's Law No. 5 on Agrarian Principles, which dealt with the right to control the state and administer land. Regulations governing Land Banks are now contained in Articles 125 to 135 of the Job Creation Act or Law No. 11 of 2020. The central government establishes land banks. A land bank agency is a unique type of government body that controls land. The land bank's assets are distinct from other state assets. The land bank agency is responsible for planning, acquiring, procuring, managing, utilizing, and distributing land. ${ }^{22}$

The land bank agency ensures land availability in the public interest, social interests, national development interests, economic fairness, land consolidation, and agricultural reform, all within the framework of a just economy. At least 30\% (30\%) of state-designated land for land bank is available for agrarian reform. The land bank agency operates in an open, accountable, and non-profit manner when performing its tasks and authorities. ${ }^{23}$

The land bank's assets may be derived from the State Revenue and Expenditure Budget, from its own revenues, through state equity participation, or from other legal sources in accordance with applicable law. Management rights are granted to land held by the land bank agency. Cultivation rights, building use rights, and use rights are all types of land rights that can be awarded. The period of the right to use the building above and beyond the right of management may be extended and renewed if the building has been used and or utilized in line with the purpose for which the right was granted. To encourage investment, the holder of the right to administer land bank entities is empowered to develop a master plan; assist

${ }^{22}$ Raquel Breitenbach and Janaína Balk Brandão, 'Factors That Contribute to Satisfaction in Cooperator-Cooperative Relationships', Land Use Policy, 105.April (2021) <https://doi.org/10.1016/j.landusepol.2021.105432>.

${ }^{23}$ Tomás Andrade da Cunha Dias and others, 'Global Potential Assessment of Available Land for Bioenergy Projects in 2050 within Food Security Limits', Land Use Policy, 105.March (2021) <https://doi.org/10.1016/j.landusepol.2021.105346>. 
in the facilitation of business licensing and approval; conduct land acquisition; and establish service fees. ${ }^{24}$

The Central Government is responsible for supervising and controlling the usage and/or exploitation of land subject to management rights in line with applicable laws and regulations. The land bank's administrative structure is composed of committees, a Supervisory Board, and an Implementing Body. Additional information on the establishment of a land bank is contained in Government Regulation (PP) No. 64 of 2021, which became effective on April 29, 2021. The Land Bank has the following responsibilities in carrying out its functions to plan long-term, mediumterm, and annual activities, to acquire land that can be sourced from the government and other parties, to acquire land for development in the public interest or through direct acquisition, to manage land through development, maintenance, and security activities, and land control, to utilize land through collaboration with other parties; and to distribute land through provision and distribution..$^{25}$

According to Government Regulation (PP) No. 64 of 2021, the Land Bank is an Indonesian legal body with its headquarters in the capital and representatives throughout the country. As a result, if the Land Bank provisions in the Job Creation Act continue to be enforced, there will be duplication or overlap of authorities. The Land Bank's power will supersede that of the Minister/head of regional office/head of land office. Juridically, the minister determines and grants permission to a person to enjoy HPL through the head of the regional office or the head of the land office. ${ }^{26}$

This is in accordance with the provisions of PMA 9/1999 and PP 40/1996. The procedure for giving ownership rights to residential land is also more precisely defined in the Decree of the State Minister of Agrarian Affairs/Head of the National Land Agency No. 6 of 1998 on the Granting of Ownership Rights to Residential Land. Article 2 states that property rights are registered by submitting an application to the head of the district/municipality land office. The people's desire of owning land with ownership rights will be impossible to realize in the presence of a Land

${ }^{24}$ Agung Indrajit and others, 'Implementation of the Spatial Plan Information Package for Improving Ease of Doing Business in Indonesian Cities', Land Use Policy, 105 (2021), 105338 <https://doi.org/10.1016/j.landusepol.2021.105338>.

${ }^{25}$ Nora Annesi and others, 'Integrating the 2030 Agenda at the Municipal Level: Multilevel Pressures and Institutional Shift', Land Use Policy, 105.March (2021), 105424 <https://doi.org/10.1016/j.landusepol.2021.105424>.

${ }^{26}$ Rada Kong and others, 'Investigating Farmers' Decision-Making in Adoption of Conservation Agriculture in the Northwestern Uplands of Cambodia', Land Use Policy, 105.March (2021), $105404<$ https://doi.org/10.1016/j.landusepol.2021.105404>. 
Bank, as property rights are not items that can be demanded from the Land Bank or land rights that can be awarded on Land Bank-owned HPL land. ${ }^{27}$

The Land Bank may issue only HGB, HGU, or Right of Use on HPL land. According to this provision, the Land Bank's objective is to issue land rights for economic interests, not for settlement/residence. Additionally, while a dwelling may be erected on land with HGB or Hak Guna, the enjoyment is not superior to that of other land rights, such as housing or flats, because property rights confer privileges on other land rights. In the field of law, there is a principle known as Lex superior derogat legi inferior, which states that higher-level legal standards trump lower-level legal standards. If this approach is applied to the Job Creation Law and other legislative regulations, the Employment Creation Law will apply, and the minister, acting through the regional office head or land office head, will lose his authority, as the Land Bank will take its place. The duty that has been replaced is connected to HPL management. ${ }^{28}$

The existence of this Land Bank will present a challenge to the administration that began the land management agency's establishment. Among the Land Bank's difficulties are the following which interests will take precedence over investment interests or equitable economic interests in the provision and distribution of land, there is a conflict of authority between the Land Bank and the Minister responsible for land or the Head of the Land Office/Head of the Land Regional Office, and expectations of reducing the burden of the case in court due to consignment (objection of compensation) for land acquisition for the public interest must be maximized.

\section{The Success of a Land Bank is Determined by Numerous Factors}

There are various variables that contribute to a land bank's success or failure, including the following: first, regulatory factors; regulations are advised for land banks in the form of laws, which confers binding legal power on them. The regulation will compel the land bank to operate in accordance with its function and purpose, thereby promoting justice and increasing people's wealth. Apart from that, because the land bank involves a large number of parties, laws will ensure that their interests are balanced (government, private sector, community). Land bank regulations should

${ }^{27}$ Ellen D. Moss, Darren M. Evans, and Jonathan P. Atkins, 'Investigating the Impacts of Climate Change on Ecosystem Services in UK Agro-Ecosystems: An Application of the DPSIR $\begin{array}{lllll}\text { Framework', Land Use Policy, 105.March } & & \text { (2021), }\end{array}$ <https://doi.org/10.1016/j.landusepol.2021.105394>.

${ }_{28}$ Charles Chavunduka, Romeo Dipura, and Vimbai Vudzijena, 'Land, Investment and Production in Agrarian Transformation in Zimbabwe', Land Use Policy, 105.March (2021), 105371 <https://doi.org/10.1016/j.landusepol.2021.105371>. 
contribute to aspects of improving the welfare of the people in order to achieve prosperity, such as increasing the welfare of the poor through land distribution, providing physical land for sustainable development for both public and commercial interests, and being able to control land prices at all levels. Public. ${ }^{29}$

Second, the institutional dimension of land banks. For Indonesia, land bank operators should be public legal entities. This is because land banks have significant authority and duty regarding the general welfare of the society, and hence the government must be actively involved in their implementation. This land bank can perform the functions of the National Land Agency, including coordinating policies and planning in the land sector by developing plans for the supply, designation, use, and maintenance of land through land use in level II regions, supervising and controlling land ownership through monitoring and evaluation of land use and utilization, as well as in the context of land redistribution, including land consolidation and conducting land managment. ${ }^{30}$

Thirdly, there is the issue of land bank financing. The issue of land bank finance is critical, particularly during the implementation stage. Land bank financing is contingent on a number of elements, including the land bank's organization, mission, and size of operation. As a result, land banks are extremely reliant on the existence of secure and permanent funding sources. In the field of land bank financing, there are normally two types of assistance available, namely program support and financial assistance. This aid is typically supplied to a country by a government or an international financing agency and is tied to specific development initiatives and projects. This support is offered in the form of financing facilities that can take the shape of grants, loans, or investments to finance various development projects. Government entities, donor agencies, non-profit/nongovernmental organizations, and financial institutions typically provide this financing. ${ }^{31}$

Numerous benefits accrue from the presence of a land bank in Indonesia. To begin, there is always the availability of land for development, ensuring that the government's and private sector's development goals are not

${ }^{29}$ Begue Angélique, Longépée Esméralda, and Laques Anne-Elisabeth, 'Local Public Authorities' and French Mainland Landscape Advisers' Perception of Landscape in Mayotte Island: The Issues of Quality of Life in a Developing Region', Land Use Policy, 105.March (2021) <https://doi.org/10.1016/j.landusepol.2021.105402>.

${ }^{30}$ Luregn Lenggenhager and Maano Ramutsindela, ‘Property Killed a Peace Park Dream: The Entanglement of Property, Politics and Conservation along the Gariep', Land Use Policy, 105.March (2021), $105392<$ https://doi.org/10.1016/j.landusepol.2021.105392>.

${ }^{31}$ Murat Okumah and others, 'The Role of Experiential Learning in the Adoption of Best Land Management Practices', Land Use Policy, 105.September 2020 (2021), 105397 <https://doi.org/10.1016/j.landusepol.2021.105397>. 
harmed. Second, investors will be attracted by the constant availability of land for development reasons. Investors that made early investments have incurred no losses as a result of the lengthy land acquisition procedure. Thirdly, effectiveness. Historically, land acquisition activities have been fraught with difficulties and prolonged due to the issue of compensating value. ${ }^{32}$

The price of land in a particular area skyrocketed considerably during the property acquisition process. Fourth, the land bank can help maintain stable land prices. When the government decides to develop a region, the price of land typically climbs instantly. Naturally, this development strategy will include supporting infrastructure that will serve as a new economic growth area. Naturally, with a land bank that has reserved property from a variety of sources, the increase in land prices in an area when it is needed is not significant. Fifth, land banks can supply land for social uses, particularly in certain circumstances, such as catastrophe recovery. Because land is easily available, catastrophe victims can be relocated and assisted with post-disaster recovery fast. ${ }^{33}$

For Indonesia, the Land Banking concept can be applied through a land acquisition method that protects existing community rights and adheres to government regulations for state properties. Numerous land items are available for reservation as land bank objects. Several criteria for land bank objects include former HGU land, abandoned land, special social assistance land handed over by the developer, IBRA asset lands, unused land assets of departments/non-departmental government agencies/local governments, state land resulting from rights revocation, state land resulting from land acquisition, and land owned by BUMN/BUMD.

\section{Conclusion}

Based on the results of the discussion above, it can be concluded that, the land bank is a particular agency that manages the land and functions to carry out land planning, acquisition, procurement, management, utilization, and distribution. According to Law Number 11 of 2020 concerning Job Creation, the Land Bank aims to accommodate several abandoned and unoccupied lands to be utilized by the state based on public interest, which will then be distributed to the community. The existence of a land bank is an effort by the government to provide land for the public interest and for people who need land. If

32 Jae Teuk Chin, 'The Shifting Role of Public-Private Partnerships in Vacant Property $\begin{array}{lllll}\text { Redevelopment', Land Use Policy, } & \text { 105.April (2021), }\end{array}$ <https://doi.org/10.1016/j.landusepol.2021.105430>.

${ }^{3}$ Richard J. Dunning, Tom Moore, and Craig Watkins, 'The Use of Public Land for House Building in England: Understanding the Challenges and Policy Implications', Land Use Policy, 105.April (2021), 105434 <https:/ / doi.org/10.1016/j.landusepol.2021.105434>. 
appropriately implemented, this institution will reduce the case against the value of land compensation for the public interest in the Court.

\section{Refrences}

Akkaya Aslan, Şerife Tülin, 'Evaluation of Land Consolidation Projects with Parcel Shape and Dispersion', Land Use Policy, 105.March (2021) <https:/ / doi.org/10.1016/j.landusepol.2021.105401>

Angélique, Begue, Longépée Esméralda, and Laques Anne-Elisabeth, 'Local Public Authorities' and French Mainland Landscape Advisers' Perception of Landscape in Mayotte Island: The Issues of Quality of Life in a Developing Region', Land Use Policy, 105.March

(2021) <https:/ / doi.org/10.1016/j.landusepol.2021.105402>

Annesi, Nora, Massimo Battaglia, Patrizia Gragnani, and Fabio Iraldo, 'Integrating the 2030 Agenda at the Municipal Level: Multilevel Pressures and Institutional Shift', Land Use Policy, 105.March (2021), 105424 <https://doi.org/10.1016/j.landusepol.2021.105424>

Breitenbach, Raquel, and Janaína Balk Brandão, 'Factors That Contribute to Satisfaction in Cooperator-Cooperative Relationships', Land Use Policy, 105.April (2021) <https:// doi.org/10.1016/j.landusepol.2021.105432>

Caffyn, Alison, 'Broiler Battles: Contested Intensive Poultry Unit Developments in a Policy Void', Land Use Policy, 105.April (2021), 105415 <https:/ / doi.org/10.1016/j.landusepol.2021.105415>

Chavunduka, Charles, Romeo Dipura, and Vimbai Vudzijena, 'Land, Investment and Production in Agrarian Transformation in Zimbabwe', Land Use Policy, 105.March (2021),

105371 <https:/ / doi.org/10.1016/j.landusepol.2021.105371>

Chin, Jae Teuk, 'The Shifting Role of Public-Private Partnerships in Vacant Property Redevelopment', Land Use Policy, 105.April (2021), 105430 <https:/ / doi.org/10.1016/j.landusepol.2021.105430>

Danley, Brian, Therese Bjärstig, and Camilla Sandström, 'At the Limit of Volunteerism? Swedish Family Forest Owners and Two Policy Strategies to Increase Forest Biodiversity', Land Use Policy, 105.March (2021) <https://doi.org/10.1016/j.landusepol.2021.105403> 
Dian, Resti, and Suviwat Jenvitchuwong, 'Implementation of Halal Product Assurance in the Pharmaceutical Sector in Indonesia', Journal of Human Rights, Culture and Legal System, 1.3 (2021), 164-79 <https://doi.org/https://doi.org/10.53955/jhcls.v1i3.19>

Dias, Tomás Andrade da Cunha, Electo Eduardo Silva Lora, Diego Mauricio Yepes Maya, and Oscar Almazán del Olmo, 'Global Potential Assessment of Available Land for Bioenergy Projects in 2050 within Food Security Limits', Land Use Policy, 105.March <https://doi.org/10.1016/j.landusepol.2021.105346>

(2021)

Dunning, Richard J., Tom Moore, and Craig Watkins, 'The Use of Public Land for House Building in England: Understanding the Challenges and Policy Implications', Land Use Policy, 105.April (2021), 105434 <https://doi.org/10.1016/j.landusepol.2021.105434>

Gonzalez-Martinez, Ana Rosa, Roel Jongeneel, Hans Kros, Jan Peter Lesschen, Marion de Vries, Joan Reijs, and others, 'Aligning Agricultural Production and Environmental Regulation: An Integrated Assessment of the Netherlands', Land Use Policy, 105.773499 (2021), 105388 <https://doi.org/10.1016/j.landusepol.2021.105388>

Hérivaux, C., F. Vinatier, M. Sabir, F. Guillot, and J. D. Rinaudo, 'Combining Narrative Scenarios, Local Knowledge and Land-Use Change Modelling for Integrating Soil Erosion in a Global Perspective', Land Use Policy, 105.March 2020 (2021) <https://doi.org/10.1016/j.landusepol.2021.105406>

Indrajit, Agung, Bastiaan van Loenen, Suprajaka, Virgo Eresta Jaya, Hendrik Ploeger, Christiaan Lemmen, and others, 'Implementation of the Spatial Plan Information Package for Improving Ease of Doing Business in Indonesian Cities', Land Use Policy, $105 \quad$ (2021), 105338 <https:/ / doi.org/10.1016/j.landusepol.2021.105338>

Iqra, Moh, Syabani Korompot, and Al-fatih David, 'The Principle of Equality Before the Law in Indonesian Corruption Case: Is It Relevant?', Journal of Human Rights, Culture and Legal System, 1.3 (2021), 135-46

Kabigi, B., Walter T. de Vries, and H. Kelvin, 'A Neo-Institutional Analysis of Alternative Land Registration Systems in Tanzania: The Cases of Babati and Iringa Districts', Land Use Policy, 105.April (2021), 105435 <https://doi.org/10.1016/j.landusepol.2021.105435>

Kim, Kon, Blaž Križnik, and Krystallia Kamvasinou, 'Between the State and 
Citizens: Changing Governance of Intermediary Organisations for Inclusive and Sustainable Urban Regeneration in Seoul', Land Use Policy, 105.March (2021) <https://doi.org/10.1016/j.landusepol.2021.105433>

Kong, Rada, Jean Christophe Castella, Vuthy Suos, Vira Leng, Sovann Pat, Jean Christophe Diepart, and others, 'Investigating Farmers' Decision-Making in Adoption of Conservation Agriculture in the Northwestern Uplands of Cambodia', Land Use Policy, 105.March (2021), 105404 <https://doi.org/10.1016/j.landusepol.2021.105404>

Lenggenhager, Luregn, and Maano Ramutsindela, 'Property Killed a Peace Park Dream: The Entanglement of Property, Politics and Conservation along the Gariep', Land Use Policy, 105.March (2021), 105392 <https://doi.org/10.1016/j.landusepol.2021.105392>

Liou, Yuei An, Kim Anh Nguyen, and Le Thu Ho, 'Altering Urban Greenspace Patterns and Heat Stress Risk in Hanoi City during Master Plan 2030 Implementation', Land Use Policy, 105 (2021), 105405 <https:/ / doi.org/10.1016/j.landusepol.2021.105405>

Mishra, Utkarsh K, and Abhishek Negi, 'Should Trade Remedies Be Eliminated from WTO : A Response to Tania Voon', Journal of Human Rights, Culture and Legal System, 1.3 (2021), 194-200

Moss, Ellen D., Darren M. Evans, and Jonathan P. Atkins, 'Investigating the Impacts of Climate Change on Ecosystem Services in UK Agro-Ecosystems: An Application of the DPSIR Framework', Land Use Policy, 105.March (2021), 105394 <https:// doi.org/10.1016/j.landusepol.2021.105394>

Oktora, Arif Purnama, and Hilaire Tegnan, 'Strategy for Implementing Operations to Handle the Crime of Narcotics', Journal of Human Rights, Culture and Legal System, 1.3 (2021), 201-13

Okumah, Murat, Julia Martin-Ortega, Pippa J. Chapman, Paula Novo, Rachel Cassidy, Christopher Lyon, and others, 'The Role of Experiential Learning in the Adoption of Best Land Management Practices', Land Use Policy, $\begin{array}{lll}\text { 105.September } 2020 & \text { (2021), }\end{array}$ <https://doi.org/10.1016/j.landusepol.2021.105397>

Popović, Svetislav G., Milica Dobričić, and Sanja Vlahović Savić, 'Challenges of Sustainable Spatial Development in the Light of New International Perspectives - The Case of Montenegro', Land Use Policy, 105.April (2021) <https://doi.org/10.1016/j.landusepol.2021.105438> 
Pourzakarya, Maryam, and Somayeh Fadaei Nezhad Bahramjerdi, 'CommunityLed Regeneration Practice in Ghalam Gudeh District, Bandar Anzali, Iran: A Participatory Action Research (PAR) Project', Land Use Policy, 105.April (2021), 105416 <https:/ / doi.org/10.1016/j.landusepol.2021.105416>

Sari, Dwi Amalia, Chris Margules, Han She Lim, Febrio Widyatmaka, Jeffrey Sayer, Allan Dale, and others, 'Evaluating Policy Coherence: A Case Study of Peatland Forests on the Kampar Peninsula Landscape, Indonesia', Land $\begin{array}{llll}\text { Use } & \text { Policy, } & 105.31 & \text { (2021), }\end{array}$ <https:/ / doi.org/10.1016/j.landusepol.2021.105396>

Smith, Tonya, and Janette Bulkan, 'A “New Relationship"? Reflections on British Columbia's 2003 Forest Revitalization Plan from the Perspective of the Lil'wat First Nation', Land Use Policy, 105.April (2021), 105345 <https://doi.org/10.1016/j.landusepol.2021.105345>

Sofiana, Ratna, Satria Utama, and Abdur Rohim C, 'The Problems of Halal Certification Regarding Consumer Protection in Malaysia and Indonesia', Journal of Human Rights, Culture and Legal System, 1.3 (2021), 180-93 <https:/ / doi.org/https://doi.org/10.53955/jhcls.v1i3.16>

Sroka, Robert, 'Does the Arena Matter? Comparing Redevelopment Outcomes in Central Dallas Tax Increment Financing Districts', Land Use Policy, 105.March (2021), 105431 <https:/ / doi.org/10.1016/j.landusepol.2021.105431>

Tadesse, Tewodros, Tsegay Berhane, Dawit W. Mulatu, and Meley Mekonen Rannestad, 'Willingness to Accept Compensation for Afromontane Forest Ecosystems Conservation', Land Use Policy, 105.September 2020 (2021), 105382 <https:// doi.org/10.1016/j.landusepol.2021.105382>

Triasari, Devi, 'Right to Sanitation : Case Study of Indonesia', Journal of Human Rights, Culture and Legal System, 1.3 (2021), 147-63 <https://doi.org/10.53955/jhcls.v1i3.20> 